\title{
PREPOZNAVANJE IN EVIDENTIRANJE
} MEJIC: PREVERJANJE RAZLIČNIH METOD NA PILOTNEM OBMOČJU LJUBLJANSKEGA BARJA

Izvirni znanstveni članek COBISS 1.01

DOI: $10.4312 /$ dela.56.5-51

\section{Izvleček}

Mejice so manj (pre)poznan element v kulturni pokrajini. V Sloveniji je v uradno evidenco vključenih 4522 mejic v skupni dolžini 458,5 km. Zaradi različnih dejavnikov se njihovo število in kakovost zmanjšujeta. Ker gre za pokrajinsko rastlinsko prvino, ki se v prostoru hitro spreminja, je za njeno ohranjanje in upravljanje pomembno ustrezno prepoznavanje in evidentiranje. Preverili smo več postopkov prepoznavanja mejic. Z uporabo lidarsko zajetih podatkov smo razvili dva pristopa in ju ovrednotili $z$ vidika njune nadaljnje uporabnosti. Ugotovili smo, da je za učinkovito prepoznavanje in evidentiranje mejic pomembna ustrezna kombinacija metod, tudi geografsko terensko delo. Za ohranjanje mejic bodo, poleg metodološko ustreznega in ažurnega evidentiranja, odločilni medsektorsko usklajeni ukrepi ter ciljno ozaveščanje kmetov in širše javnosti o raznovrstnih funkcijah mejic v kulturni kmetijski pokrajini.

Ključne besede: krajinska prvina, mejice, lidarsko zajeti podatki, operacija Ohranjanje mejic, Ljubljansko barje

${ }^{\star}$ Oddelek za geografijo, Filozofska fakulteta Univerze v Ljubljani, Aškerčeva cesta 2, SI-1000 Ljubljana

**Bolkova ulica 16, SI-1235 Radomlje

e-pošta: barbara.lampic@ff.uni-lj.si, alenka14kastelic@gmail.com 


\section{UVOD}

Zmanjševanje pokrajinske pestrosti in neustrezno upravljanje s posameznimi sestavinami pokrajine sta med pomembnimi dejavniki izgube biotske raznovrstnosti v večini držav Evropske unije in Sloveniji. Krajinske značilnosti (izraz krajinske značilnosti ali prvine uporabljamo na mestih, kjer povzemamo besedilo uradnih dokumentov, sicer uporabljamo izraz pokrajinske značilnosti) namreč povečujejo možnost ohranjanja biotske raznovrstnosti predvsem kmetijskih ekosistemov (Resolucija o Nacionalnem programu ..., 2020). Številne, za kmetijsko pridelavo vitalne ekosistemske storitve (kot npr. opraševanje, naravno zatiranje škodljivcev v kmetijstvu, zmanjševanje negativnih vplivov vetra, suše ipd.), so neposredno in močno odvisne od ustrezne zastopanosti pokrajinskih značilnosti v (kmetijski) kulturni pokrajini (Stališče stičišča SVARUN, 2020).

Pri obravnavanju (po)krajinskih značilnosti v prispevku sledimo opredelitvi krajinskih značilnosti v ciljnem raziskovalnem projektu (Golobič in sod., 2015), kjer so razvrščene v štiri skupine in vključujejo geomorfološke in rastlinske krajinske prvine (grbinaste travnike, kraške kotanje, balvane, terase ipd.), rastlinske krajinske prvine (gozdne zaplate, mejice, obvodna vegetacija, vlažni travniki ipd.), vodne krajinske prvine (lokalna zamočvirjenja, nizka in visoka barja, jarki) in grajene objekte (suhozidi).

Manjša pokrajinska pestrost je največkrat posledica sprememb v uporabi (sodobnih) kmetijskih tehnologij, velike racionalizacije proizvodnih stroškov, modernizacije in intenzifikacije kmetijske proizvodnje. Sočasno na območjih z manj ugodnimi naravnimi razmerami za kmetijsko pridelavo prihaja do opuščanja rabe in zaraščanja kmetijske pokrajine. K spremembam prispevajo tudi povsem administrativni razlogi, ki so vezani na pogoje upravičenosti podpor kmetijskim gospodarstvom, ter posledično prizadevanja kmetov za povečanje upravičenih kmetijskih površin, saj pokrajinske značilnosti večinoma niso priznane kot upravičena raba za prejemanje podpor iz naslova ukrepov kmetijske politike (Golobič in sod., 2015; Stališče stičišča SVARUN, 2020). Zmanjševanje, ponekod pa celo izginjanje pokrajinskih značilnosti je povezano tudi $\mathrm{z}$ urbanizacijo in fragmentacijo prostora, turizmom in rekreacijo, razrastom invazivnih (tujerodnih) rastlinskih vrst in podnebnimi spremembami.

Okoljska vizija zadnje Resolucije o nacionalnem programu varstva okolja za obdobje 2020-2030 je ohranjena narava in zdravo okolje v Sloveniji in zunaj nje, kar omogoča in bo omogočalo kakovostno življenje zdajšnjim in prihodnjim generacijam. Tudi tu v okviru varovanja, ohranjanja in izboljševanja naravnega kapitala Slovenije med cilji naslavljajo ohranjanje tistih pokrajinskih značilnosti, ki so pomembne za biotsko raznovrstnost. V resoluciji ugotavljajo, da so krajinska pestrost in krajinske značilnosti pretežno odvisne od naravnih procesov in socialno-ekonomskih razmer (Resolucija o Nacionalnem programu ..., 2020). V Sloveniji zaradi raznolikih geografskih razmer in dolge tradicije kultiviranja zemljišč (še) prevladuje mozaična 
pokrajina, katere sestavni deli so drobne strukture (vodotoki in drugi vodni pojavi, posamezno drevje ali skupine dreves, žive meje, mejice, suhozidi, drevoredi), ekstenzivne kmetijske površine (npr. malo gnojeni ali negnojeni travniki in pašniki), mozaični preplet njiv z različnimi kulturami in gozdovi, s katerimi trajnostno gospodarijo. T. i. "poenostavljanje krajine«, ki smo mu priča marsikje v Sloveniji, vodi v izginjanje naravnih struktur in kulturnih elementov, zmanjšuje mozaičnost ter s tem tudi krajinsko pestrost in biotsko raznovrstnost (Resolucija o Nacionalnem programu ..., 2020).

Za varstvo omenjenih pokrajinskih značilnosti je treba torej ohranjati lastnosti, zaradi katerih so deli pokrajine ali njeni elementi opredeljeni kot pokrajinska značilnost. Tu je odločilnega pomena spremljanje in usmerjanje posegov v prostor (Lampič, Kušar, Zavodnik Lamovšek, 2017).

Mejice so opredeljene kot »rastlinska krajinska prvina« (Golobič in sod., 2015). Sestavlja jih linijsko lesnato rastlinstvo (drevesa in grmovje), ki pa je lahko podvrženo številnim in hitrim spremembam. Če se za mejice ustrezno ne skrbi, stalno spreminjajo svojo dolžino in obliko. Ker gre za linijske strukture pretežno grmovne zarasti, se jih razmeroma enostavno tudi poseka. Mejice se po drugi strani tudi hitro zaraščajo, najpogosteje na tistih delih kmetijskega zemljišča, ki ga kmet zaradi slabše kakovosti, težje dostopnosti in drugih vzrokov preneha obdelovati.

Posebno pozornost smo v prispevku namenili prepoznavanju in evidentiranju mejic s pomočjo digitalnih ortofoto in lidarskih posnetkov. Njihova največja pomanjkljivost je ažurnost, saj so bili lidarsko zajeti podatki za celotno Slovenijo zajeti le enkrat, medtem ko se digitalne ortofoto posnetke posodablja na dve do štiri leta.

Za učinkovitejše ohranjanje posameznih pokrajinskih prvin (npr. grbinastih travnikov, mejic idr.), ki v kombinaciji z ostalimi sestavinami ustvarjajo pokrajinske značilnosti, je potrebno zagotavljanje podatkovnih zbirk, ki temeljijo na ustreznih načinih evidentiranja posameznih pokrajinskih prvin. Odsotnost monitoringov tako ovira sam sistem spremljanja pojava, nadzor in ustrezno ukrepanje ob negativnih procesih. Ta pomanjkljivost je bila prepoznana tudi na ravni izvajanja kmetijske politike, kjer sta v Skupnem strateškem načrtu 2023-2027 posebej izpostavljena izboljševanje ter razširitev različnih prostorskih slojev za izvedbo naravovarstvenih podintervencij, ki se bodo nanašale na mejice, mokrišča in občutljivo trajno travinje na območjih Natura 2020 idr. (MKGP, 2021).

\section{TEORETIČNA IZHODIŠČA}

Mejice so kot pomemben element v prostoru prepoznane širom po svetu. Strokovno utemeljena in $\mathrm{z}$ raziskavami dobro podprta je njihova obravnava $\mathrm{v}$ državah Zahodne Evrope in Severne Amerike (npr. Allende Álvarez, Gómez Mediavilla, López Estébanez, 2021; Allende Álvarez in sod., 2021; Graham in sod., 2018; Litza in sod., 2022). V Združenem kraljestvu jih npr. ciljno varujejo s posebnim Predpisom o varovanju 
mejic (The hedgerow regulations, 1997). Zaradi obsežnih in hitrih sprememb v prostoru (intenziviranje kmetijstva, uporaba sodobne tehnologije, širjenje urbaniziranih površin, spremembe politike upravljanja kmetijskih zemljišč) pa se na svetovni ravni soočamo z njihovim postopnim izginjanjem (Baudry, Bunce, Burel, 2000; Burel, Baudry, 1990; Molnarova, 2008) in tako ohranjanje mejic postaja vse večji izziv.

Obravnava mejic tudi terminološko še ni poenotena. V tuji literaturi se najpogosteje pojavljata dva pojma: živa meja (ang. hedge) in mejica (ang. hedgerow), vendar je njuna uporaba nekonsistentna. Živa meja predstavlja lesno komponento mejne zarasti, medtem ko mejice (hedgerow) vključujejo tudi zeliščno komponento in kanal ob mejici (Forman, Baudry, 1984). Ker v Sloveniji nimamo enega uveljavljenega termina, se uporabljajo poimenovanja, kot so živice, omejki ali živa meja. Terminološke zagate so se nekoliko razrešile $\mathrm{z}$ uvedbo operacije Ohranjanje mejic, ki se izvaja v okviru Kmetijsko okoljskih in podnebnih ukrepov (KOPOP) Skupne kmetijske politike (SKP). S to operacijo se je v kmetijskem in naravovarstvenem sektorju uveljavila oznaka mejica (MKGP, 2019).

Do razhajanj prihaja tudi pri opredelitvi minimalne dolžine mejic. V raziskavi smo izhajali iz definicije Ministrstva za kmetijstvo, gozdarstvo in prehrano (MKGP), ki mejice označuje kot vsaj 10 metrov dolge in pri krošnji največ 20 metrov široke strnjene in samostojne linije lesne vegetacije, ki morajo biti široke več kot dva metra (MKGP, 2019).

Obravnava mejic ter njihovo ustrezno upravljanje sta pomembna zaradi številnih in med seboj dopolnjujočih funkcij, ki jih mejice opravljajo. Predstavljajo prehranjevalni habitat za številne živali, kar je še posebnega pomena v intenzivno obdelani kmetijski pokrajini. So pomembni migracijski in preletni koridorji, ki med seboj povezujejo različne ekosisteme. Pomembno je, da so mejice sestavljene iz raznovrstnih avtohtonih vrst s tako razvito grmovno plastjo, ki omogoča dostop svetlobe do najnižjih plasti (Dondina in sod., 2016; Garratt in sod., 2017; Heath in sod., 2017). Mejice zmanjšujejo vplive vetra, suše, neurij in toče, kontrolirajo vodni tok ter zadržijo izpiranje hranil iz kmetijskih zemljišč v vodotoke. Na eni strani omejujejo širjenje za kmetijstvo škodljivih organizmov (MKGP, 2021), po drugi služijo kot zatočišče živalim, tako divjim kot pašnim. Velik pomen mejic $\mathrm{v}$ kmetijski pokrajini je $\mathrm{v}$ njihovem preprečevanju vetrne erozije (Earnshaw, 2004; MKGP, 2021). Kakovost zaščite je odvisna od velikosti drevja; tako je učinek vetrne zaščite 56 metrov za dvometrskim grmom in 560 metrov za 20-metrsko mejico (Forman, Baudry, 1984). Med pomembnimi ekosistemskimi storitvami je tudi uravnavanje lokalnega podnebja, saj se na območju mejic in v njihovi okolici vzpostavi posebna mikroklima (MKGP, 2021). Na območju mejic so višje vsebnosti vode in organskega ogljika v prsti, kar prispeva $\mathrm{k}$ višji produktivnosti zemljišč (Sanchez in sod., 2010). Mejice predstavljajo tudi vir surovin, med katerimi je najpomembnejši les, ki je imel pomembno vlogo predvsem v preteklosti in v deželah, kjer primanjkuje gozdnih površin (Burel, Baudry, 1990). Ima pa prisotnost mejic tudi nekatere negativne učinke, saj lahko mejice privabljajo nekatere škodljive žuželke ter 
ptice, ki škodujejo posevkom na bližnjih njivah (Farmers and hedgerow management, 2019), s povzročanjem sence pa vplivajo na količino pridelka (Oreszczyn, Lane, 2000).

Mejice prispevajo k pokrajinski pestrosti kulturne pokrajine in razbijajo njeno monotonost (Golobič in sod., 2015), pogosto pa razmejujejo posestva različnih lastnikov (Baudry, Bunce, Burel, 2000). Imajo torej velik estetski pomen, o katerem se redko piše in je o njem narejenih malo študij, a je pomemben dejavnik ohranjanja mejic (Burel, Baudry, 1990).

V Sloveniji so mejice ena izmed pokrajinskih prvin, pomembnih za ohranjanje biotske raznovrstnosti, ki so bile opredeljene v projektu Opredelitev krajinske pestrosti in značilnosti, pomembnih za ohranjanje biotske raznovrstnosti (Golobič in sod., 2015). Med krajinske prvine štejemo še npr. vodne jarke, suhozide, obvodno vegetacijo, grbinaste travnike idr. Na kmetijskih zemljiščih so te prvine ključnega pomena za ohranjanje številnih rastlinskih ter živalskih vrst, imajo pa tudi veliko drugih koristnih funkcij za človeka in samo pokrajino (Golobič in sod., 2015). Eden od ciljev Skupne kmetijske politike po letu 2020 je okrepiti prispevek kmetijstva k varstvu biotske raznovrstnosti s pomočjo varovanja pestrosti pokrajinskih prvin (Biodiversty and farmland landscapes, 2020). Skupna usmeritev za vse navedene prvine je njihovo ohranjanje predvsem v intenzivno obdelani kmetijski pokrajini in ekstenzivna raba njihove neposredne okolice. Za te prvine v Sloveniji nimamo ustreznih podatkovnih podlag za spremljanje stanja ali pa poenotenega sistema njihovega varovanja (Golobič in sod., 2015).

Slika 1: Dobro strukturirane mejice zaradi zastopanosti vseh treh slojev rastlinstva (dreves, grmovja in zelišč) opravljajo največ funkcii (Vipavska dolina) (foto: A. Kastelic).

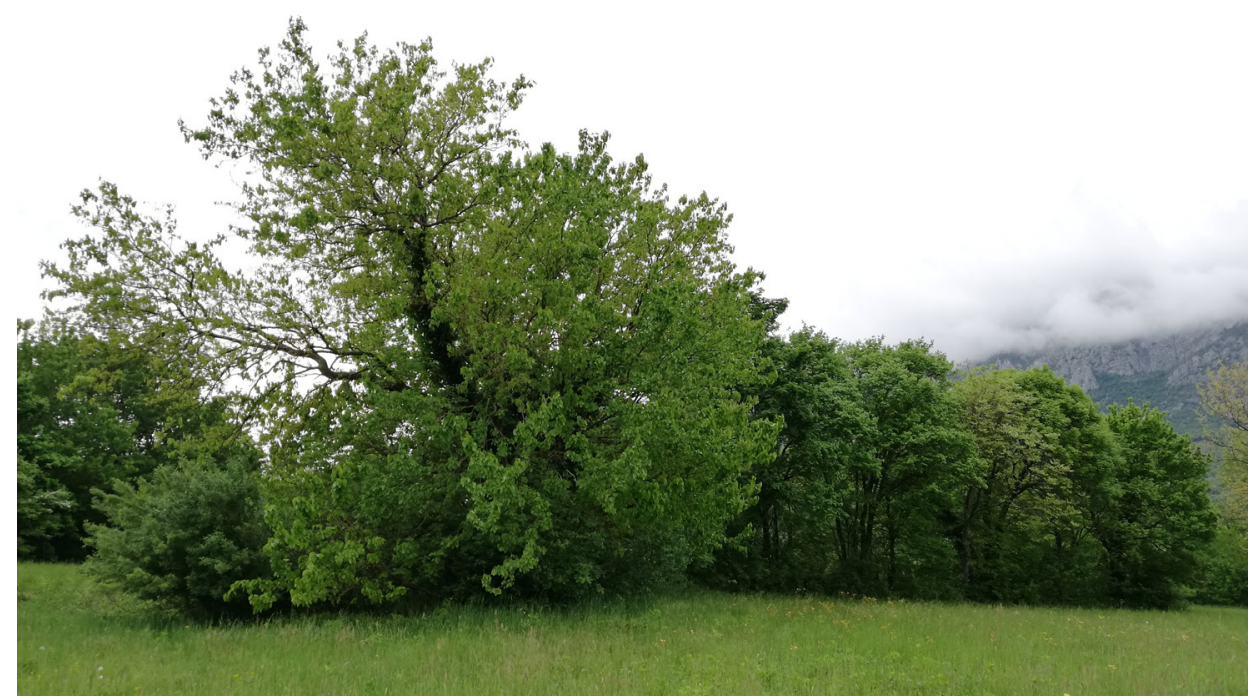


Kakovost opravljanja različnih funkcij mejic pa je odvisna predvsem od njihove strukture. Zato so se številni avtorji (Boutin in sod., 2002; Burel, Baudry, 1990; Garratt in sod., 2017) v svojih raziskavah mejic lotili njihove tipologije (npr. Allende Álvarez, Gómez Mediavilla, López Estébanez, 2021; Allende Álvarez in sod., 2021). Strinjajo se, da so najbolj kakovostne tiste mejice, ki so večvrstne, goste, sestavljene iz dreves in grmovja ter se prepletajo z drugimi mejicami, tako da sestavljajo sistem oziroma mrežo mejic (Boutin in sod., 2002; Baudry, Bunce, Burel, 2000; Forman, Baudry, 1984; Hedgerow survey handbook ..., 2007).

Za potrebe naše raziskave smo izdelali lastno, slovenskim razmeram prilagojeno tipologijo mejic (Kastelic, 2019). Končna tipologija vključuje pet tipov mejic:

1. Strukturirane mejice so tiste, ki vključujejo vse tri plasti rastlinstva: drevesno, grmovno in zeliščno. So vertikalno povezane in nudijo različne habitate za številne živalske vrste, zato so $\mathrm{z}$ naravovarstvenega vidika najbolj kakovostne.

2. Grmovne mejice so sestavljene iz grmovne in zeliščne zarasti. Grmovna zarast je gosta, ustvarja vertikalno povezanost in je težko prehodna.

3. Polstrukturirane mejice so sestavljene iz drevesne, grmovne in zeliščne zarasti. Razlika med strukturiranim in polstrukturiranim tipom je, da je pri slednjem grmovna zarast redkejša, nižja in je zato mejica bolj prehodna.

4. Drevesne mejice sestavljajo drevesa in zeliščna zarast.

5. Kombinirane mejice so daljše mejice, $v$ katerih se izmenjata najmanj dva tipa mejice. Njihove lastnosti so odvisne od tipov, ki jo sestavljajo.

Slika 2: Kombinirane mejice (kombinacija grmovne in drevesne plasti) so na Ljublianskem barju prisotne $v$ večjem številu (foto: $A$. Kastelic).

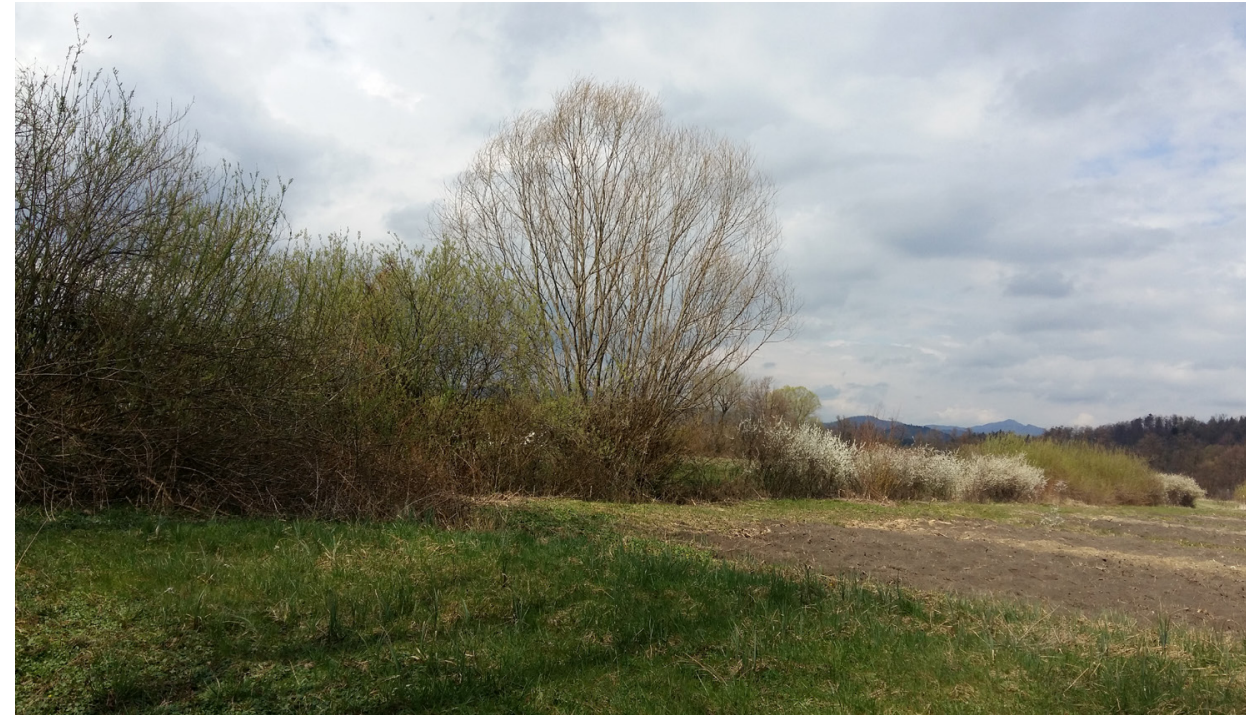


Z vidika opravljanja funkcij (za človeka, živalstvo in pokrajino) so najustreznejše strukturirane mejice, ki so sestavljene iz vseh treh slojev, sledijo grmovne in polstrukturirane mejice, medtem ko so drevesne mejice za opravljanje npr. naravovarstvenih funkcij manj primerne.

Slika 3: Strukturirane mejice na Ljublianskem barju opravljajo še posebej pomembne naravovarstvene funkciie, saj se nahajajo med intenzivnimi kmetijskimi površinami (foto: A. Kastelic).

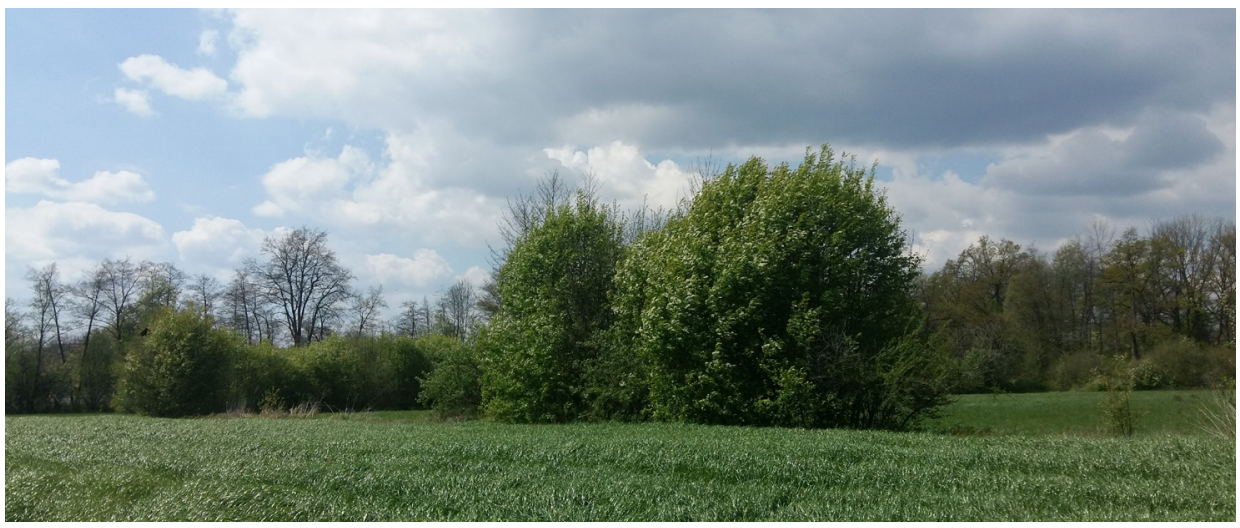

Slika 4: Drevesne mejice tvorijo drevesa in zeliščna zarast. Na sliki je primer drevesne mejice na Ljublianskem bariu, ki zaradi intenzivnega izsekavanja in čiščenja ter drugih rab izgublia svoje funkcije (foto: B. Lampič).

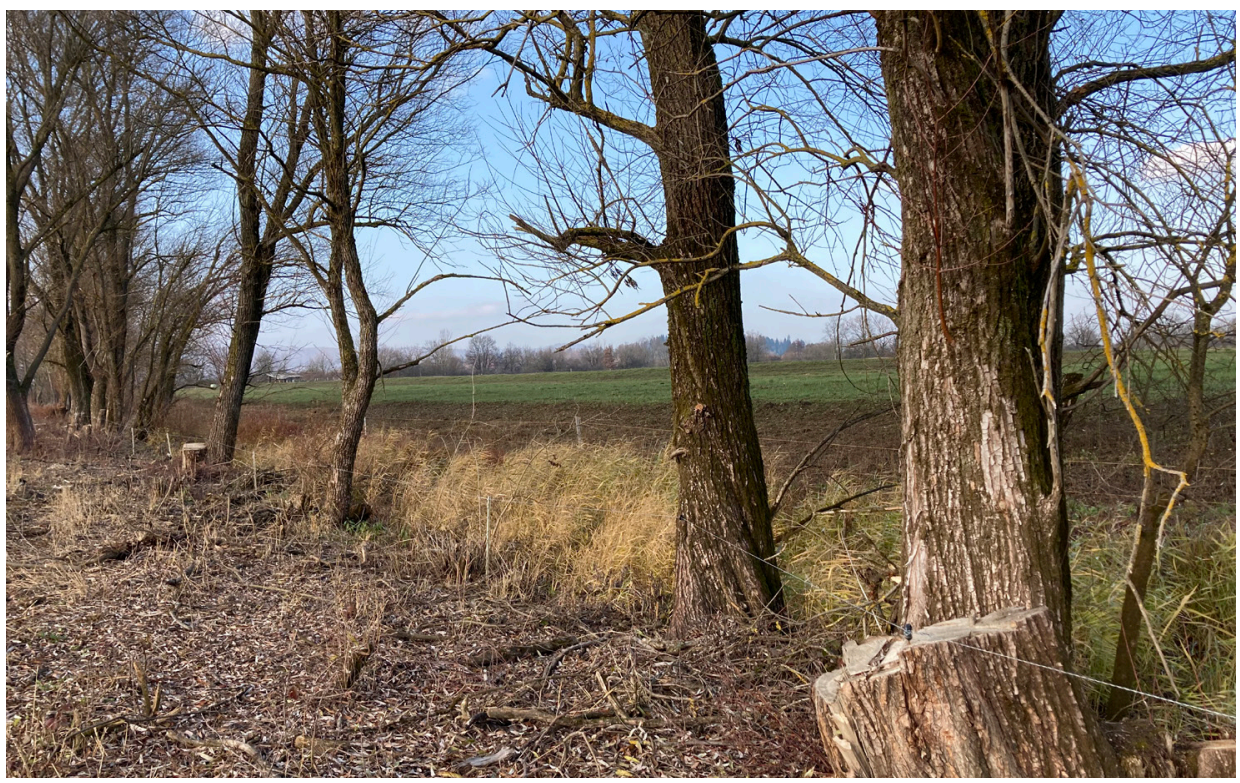




\section{PRISOTNOST IN PREPOZNAVNOST MEJIC V SLOVENIJI}

Mejice v Sloveniji so prisotne na območju celotne države, prihaja pa do precejšnjih pokrajinskih razlik. Na Krasu so npr. nastajale ob suhozidovju (Šmid Hribar, 2008), medtem ko so na Goričkem z mejicami omejevali pašnike (Domanjko, Malačič, 2009). O njihovi biološki funkciji je bilo napisanih nekaj diplomskih del, Janez Božič pa je že leta 1969 napisal delo Protivetrni nasadi (vetrobrani) v nižinskih predelih Slovenije (Premrl, Turk, 2013). Posledično o stanju mejic v Sloveniji vemo razmeroma malo, nekoliko bolj sistematično pa se spremlja tiste mejice, ki so vključene v kmetijsko operacijo Ohranjanje mejic.

Operacija Ohranjanje mejic je ena izmed operacij ukrepa KOPOP (kmetijsko-okoljska-podnebna plačila) v PRP (2014-2020, kot podinetervencija se bo izvajala tudi v programskem obdobju 2023-2027). Podpira vzdrževanje in ohranjanje mejic na različnih vrstah rabe kmetijskih zemljišč in pomeni ohranjanje enega izmed pomembnih elementov kmetijske kulturne pokrajine. Operacija se izvaja vse od leta 2017, kmet pa se ob vstopu v operacijo zaveže za izvajanje vsaj za pet let. Višina plačila za izvajanje operacije znaša 1,60 EUR za tekoči meter letno (MKGP, 2019). Pri vzdrževanju mejic je treba poskrbeti za njihovo redčenje, odstranjevati suhe veje in jih obrezovati. Plačila so namenjena izpadu dohodka kmeta (ponekod zmanjšan pridelek v senci, težja obdelava) in za dodatno delo, vezano na vzdrževanje mejic (Čus, 2019; Žvikart, 2019). Najpomembnejše je njihovo obrezovanje (na dve leti), vendar ne v času gnezdenju ptic (med 1. marcem in 30. septembrom) (MKGP, 2019).

Preglednica 1: Število in dolžina mejic, vključenih v operacijo Ohranjanje mejic na sedmih območiih Natura 2000.

\begin{tabular}{|l|c|c|c|c|c|}
\hline Območje Natura 2000 & $\begin{array}{c}\text { Število } \\
\text { mejic }\end{array}$ & $\begin{array}{c}\text { Skupna } \\
\text { dolžina (m) }\end{array}$ & $\begin{array}{c}\text { Najdaljša } \\
\text { mejica (m) }\end{array}$ & $\begin{array}{c}\text { Najkrajša } \\
\text { mejica (m) }\end{array}$ & $\begin{array}{c}\text { Povprečna } \\
\text { dolžina (m) }\end{array}$ \\
\hline $\begin{array}{l}\text { Krakovski gozd - } \\
\text { Šntjernejsko polje }\end{array}$ & 404 & 44.875 & 792 & 11 & 111 \\
\hline dolina Reke & 383 & 27.833 & 421 & 10 & 73 \\
\hline dolina Vipave & 123 & 8.783 & 328 & 15 & 71 \\
\hline Planinsko polje & 298 & 27.368 & 586 & 13 & 92 \\
\hline Ljubljansko barje & 2.720 & 290.876 & 1.254 & 11 & 107 \\
\hline Drava & 286 & 32.793 & 691 & 14 & 115 \\
\hline Mura & 308 & 26.030 & 545 & 15 & 85 \\
\hline Skupaj & 4.522 & 458.558 & 1.254 & 10 & 101 \\
\hline
\end{tabular}

Vir podatkov: MKPG, $2018 \mathrm{~b}$. 
Operacija Ohranjanje mejic se je v letu 2019 izvajala na sedmih območjih Nature 2000 (Krakovski gozd - Šentjernejsko polje, dolina Reke, dolina Vipave, Planinsko polje, Ljubljansko polje, Drava, Mura) (MKGP, 2019). V operacijo so vključena območja, kjer mejicam najbolj grozi izginotje (Žvikart, 2019). Vseh mejic v operaciji je 4522, njihova skupna dolžina pa znaša 458.558 metrov. Povprečna dolžina mejice je 101 meter, najdaljša meri kar 1254 metrov, najkrajša pa 10 m (MKGP, 2018b).

Slika 5: Prikaz območij izvajanja operacije Ohranjanje mejic v Sloveniji.

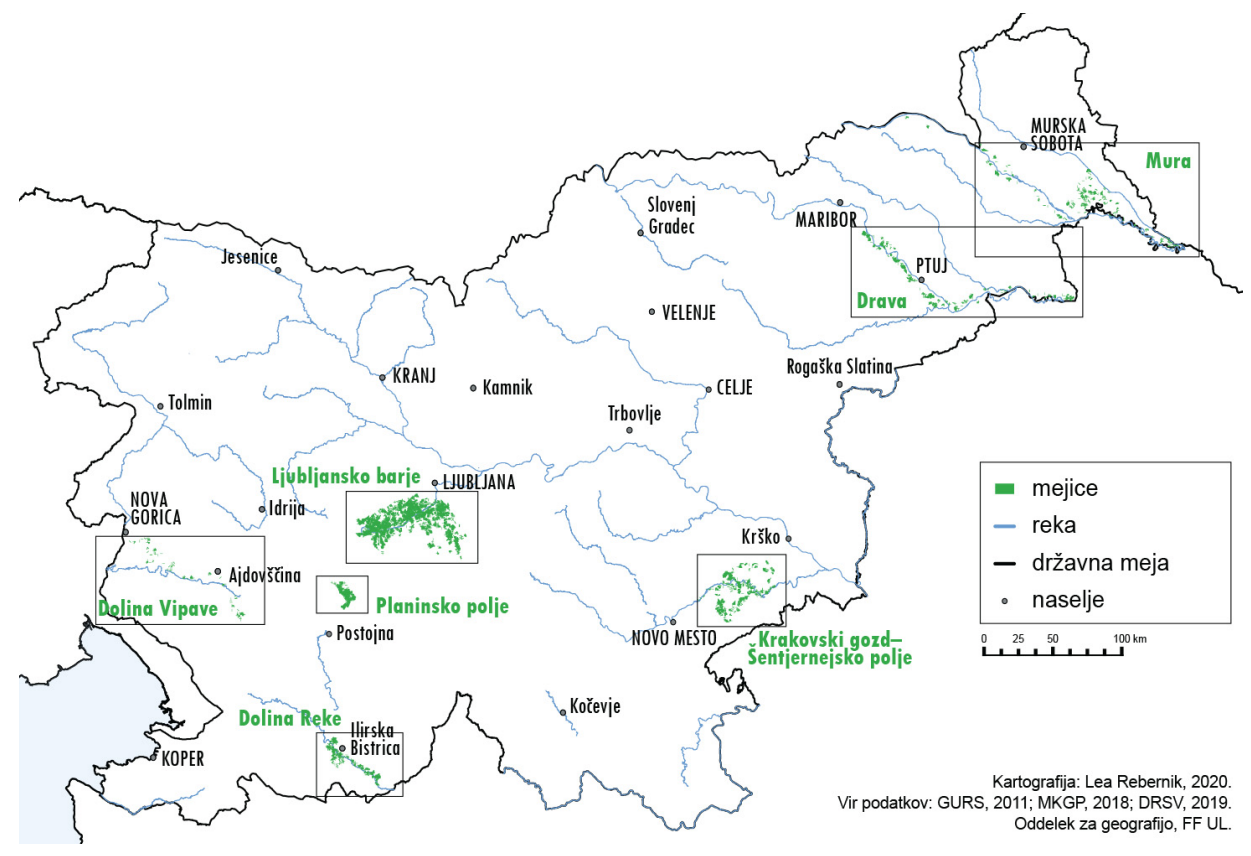

V letu 2018 so se v operacijo Ohranjanje mejic vključila 104 kmetijska gospodarstva (KMG), ki so skupaj vzdrževala 134 kilometrov mejic. V okviru operacije jim je bilo izplačanih okoli 214.400 EUR. Od tega je bila večina (kar $90 \%$ ) prijavljenih kmetov z Ljubljanskega barja, medtem ko je število v operacijo vključenih KMG na drugih območjih skromno (Čus, 2019). Razlogi za velike razlike v številu prijavljenih kmetov med območji so v številu in dolžini mejic. Na Ljubljanskem barju jih je največ, so najdaljše in so širše prisoten element v kulturni pokrajini. Na odločitev za vstop v operacijo pomembno vpliva odnos kmeta do mejice, razumevanje same operacije ter (predvsem) aktivnost in prizadevanje kmetijskih svetovalcev (Žvikart, 2019; Čuš, 2019).

Operacija Ohranjanje mejic ščiti in ohranja 4.522 mejic na sedmih območjih Nature 2000 (MKGP, 2018b). Te mejice so (bolj) varne pred posekom, pri preostalih pa še vedno redno prihaja do izsekavanja ali krčenja, saj je njihovo varovanje, tudi na 
območju Krajinskega parka Ljubljansko barje, s trenutnimi zakonskimi podlagami težko izvedljivo. Še bolj pa je zaskrbljujoče dejstvo, da nimamo podatkov in informacij, kaj se dogaja z mejicami na preostalem območju Slovenije. Nimamo nobenega podatka o njihovem številu, dolžini, strukturi in aktualnih procesih. Če neustrezna ravnanja zasledimo na bolj varovanih območjih izvajanja operacije lahko predvidevamo, da so drugod razmere še slabše. Tako npr. na območju Krajinskega parka Ljubljansko barje ugotavljajo, da so bili z izsekavanjem (torej uničenjem) mejic kršeni predpisi s področja varstva narave. Sočasno pa je kmet, po odstranitvi mejic, lahko brez ovir zemljišče (travinje) vpisal v zbirno vlogo kot njivo ter prejel kmetijska plačila. Sistem pravil in kmetijskih predpisov v Sloveniji očitno deluje na način, da omogoča izplačevanje evropskih kmetijskih plačil tudi za ravnanja, ki pomenijo krnitev narave in kršitev naravovarstvenih predpisov (Jančar, 2018).

\section{LJUBLJANSKO BARJE KOT PILOTNO OBMOČJE}

Za nadaljnje delo smo izbrali pilotno območje Ljubljansko barje, kamor smo usmerili vse nadaljnje korake raziskave, skupaj s terenskim popisom mejic. Ljubljansko barje leži v osrednji Sloveniji na južnem delu Ljubljanske kotline in obsega 120 kvadratnih kilometrov (Pavšič, 2008). Zanj je značilna mozaična pokrajina, preplet njiv, barjanskih travnikov, pašnikov, kanalov, vodotokov in mejic, ki so eden izmed pomembnejših gradnikov pokrajine (Strokovne podlage za ustanovitev ..., 2007). Glavna ovira za razvoj kmetijstva sta zamočvirjenost in talna voda; kljub temu so leta 2017 obdelovali $82 \%$ površin. Na skoraj polovici njiv je kot kulturna rastlina zastopana (silažna) koruza, kar predstavlja nevarnost, da Ljubljansko barje postane monotona monokulturna pokrajina. Velikost kmetij na Ljubljanskem barju je glede na slovenske razmere nadpovprečna (12,72 ha) (Kmetijstvo na Ljubljanskem barju, 2019).

Mejice so na Ljubljanskem barju tradicionalni pokrajinski element. Njihova razširjenost $\mathrm{v}$ preteklosti je bila še večja, predvsem ob kanalih. Bile so pomemben vir surovin (les), označevale so meje parcel različnih lastnikov, danes pa te funkcije izgubljajo. Gostota in sestava mejic se znotraj Ljubljanskega barja precej razlikujeta. Tako je v zarasti mejic na obrobju več vrb, pri mejicah v notranjosti pa prevladujejo jelše. Veliko drevesne in grmovne zarasti so posekali ob čiščenju pri vzpostavitvi grafičnih enot rabe kmetijskega gospodarstva (GERK-ov). Z intenziviranjem kmetijstva so tako za marsikaterega kmeta postale moteči element. Na Ljubljanskem barju je v operacijo Ohranjanje mejic več kmetov vključenih na zahodnem delu, na vzhodnem delu pa je njihovo število manjše. Večina kmetov v Operaciji ima preko 2000 metrov mejic, dva kmeta pa celo po 10 kilometrov mejic (Pečjak, 2019). 
Slika 6: Območje raziskave na severnem delu Ljubljanskega barja.

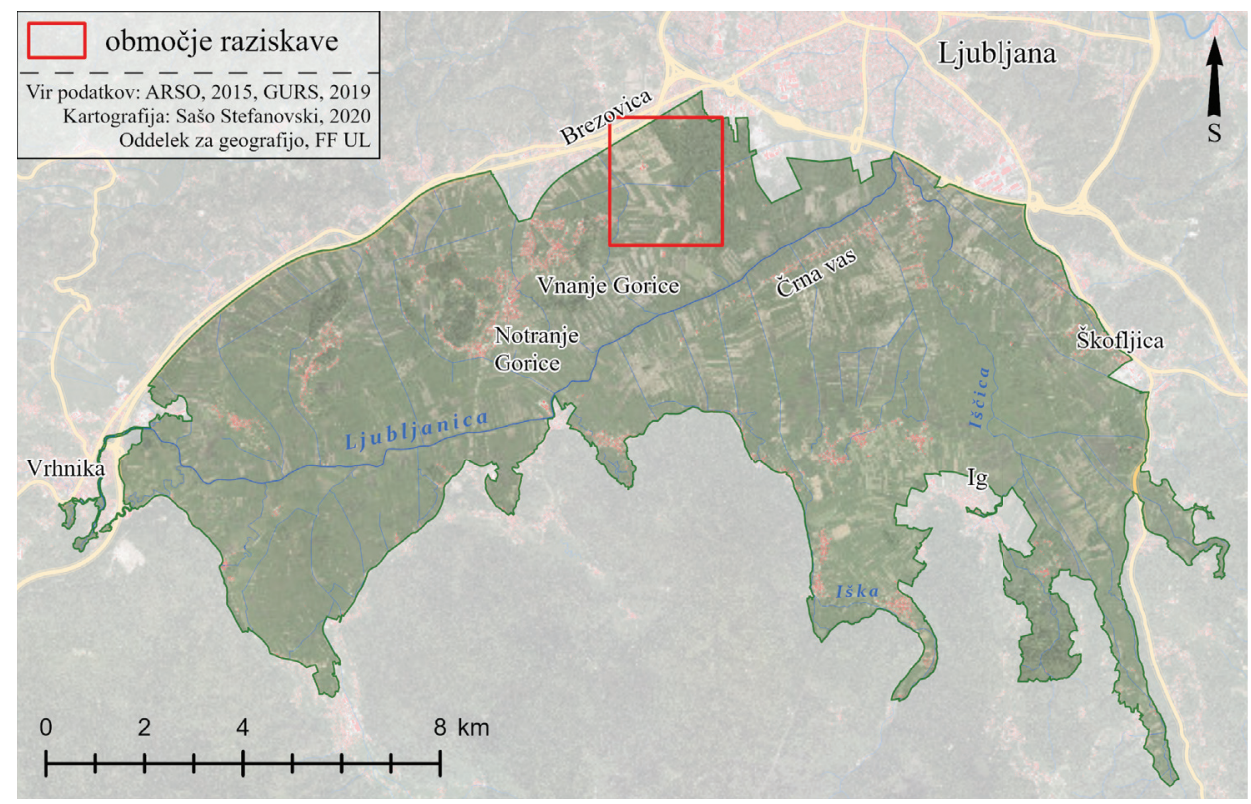

Izbrano pilotno območje znotraj Ljubljanskega barja je veliko dva kvadratna kilometra in leži na območju Nature 2000, znotraj Krajinskega parka Ljubljansko barje. Krajinski park s svojimi varstvenimi režimi mejice varuje pred sekanjem in vzdrževalnimi deli med 15. marcem in 30. septembrom (Uredba o Krajinskem parku ..., 2008), $\mathrm{v}$ praksi pa se pojavljajo težave $\mathrm{z}$ nadzorovanjem upoštevanja predpisov iz uredbe (Japelj, 2019). Na pilotnem območju prevladujejo njive (54 \%) in barjanski travniki (20\%) (MKGP, 2018a), med mejicami pa so prevladujoče strukturirane in grmovne, ki jih prepoznavamo kot najbolj kakovostna tipa (Kastelic, 2019). 
Slika 7: Značilna polstrukturirana mejica med travniki na Ljubljanskem barju (foto: A. Kastelic).

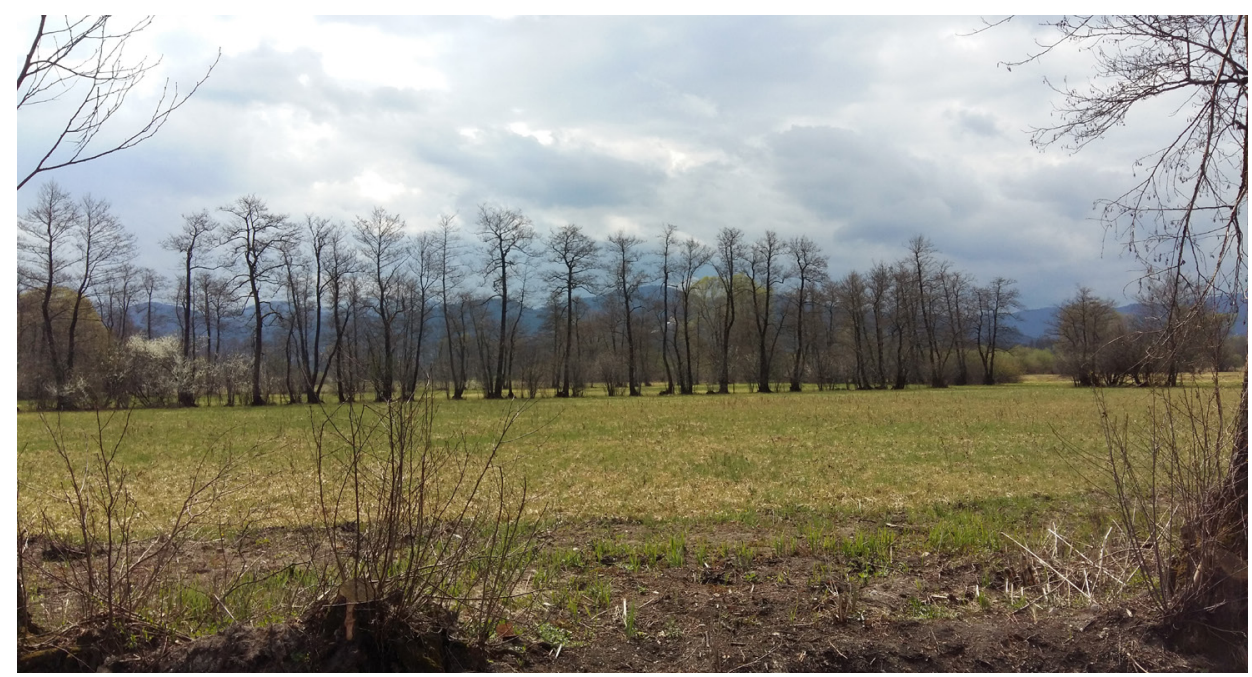

\section{METODE}

Zavod RS za varstvo narave (ZRSVN) je po pooblastilu MKGP leta 2016 pripravil prvi evidenčni sloj mejic v Sloveniji (Bucik in sod., 2017). Sloj je bil izdelan na podlagi digitalnih ortofoto posnetkov iz leta 2014, kjer so aerofotografije transformirane iz centralne $\mathrm{v}$ ortogonalno projekcijo in so mersko primerljive s kartami (Zbirke prostorskih podatkov, 2019). Zaradi implementacije operacije Ohranjanje mejic v okviru KOPOP je bil sloj pripravljen v kratkem času. Prepoznavanje mejic je temeljilo na uporabi starejših ortofoto posnetkov, zato je bila kakovost prvega evidenčnega sloja ponekod slabša, saj so bile mejice evidentirane površno ali pa je prišlo do napak zaradi sprememb v dejanski rabi oziroma odstranitvi mejic. Sloj mejic 2018 je bil dopolnjen in izboljšan na podlagi novejših ortofoto posnetkov (iz leta 2017) ter terenskih poročil (Čuš, 2019; Žvikart, 2019). Oba uradna sloja mejic (2016 in 2018) smo preverili na terenu tudi za potrebe raziskave in ugotovili številne nepravilnosti. S preliminarnim terenskim delom smo leta 2017 na severovzhodnem delu Ljubljanskega barja ugotovili razlike med dejanskim stanjem v prostoru in evidenčnim slojem mejic 2016 na kar $62 \%$ mejic (izbranega območja). Ob ponovnem terenskem preverjanju v letu 2019 (preverjali smo sloj mejic 2018) je bilo zaznanih manj razlik (Kastelic, 2019). Pokazala se je ključna vloga terenskega preverjanja stanja mejic pa tudi njegova zahtevnost in zamudnost (Bucik in sod., 2017; Kastelic, 2019).

Ker se prepoznavanje in evidentiranje mejic neposredno s pomočjo ortofoto posnetkov ter terenskim delom nista izkazala za optimalni rešitvi pri evidentiranju mejic, smo mejice identificirali še na podlagi lidarsko zajetih podatkov. Uporabili smo posnetke s portala E-vode, za katerega skrbi ARSO. Metodo smo preverili na manjšem pilotnem območju (ki je bilo predstavljeno predhodno), kjer so mejice zastopane v večjem številu, hkrati pa 
je dovolj blizu Ljubljane. Lasersko skeniranje za Ljubljansko barje je bilo izvedeno v letih 2014 in 2015 z ločljivostjo 10 točk na m² (Izvedba laserskega skeniranja ..., 2015).

Pilotno območje dveh kvadratnih kilometrov, ki leži na severu Ljubljanskega barja, vključuje različne tipe mejic, heterogena pa je tudi raba tal. Osnovni sloj lidarsko zajetih podatkov je bil filtriran na sloj LAS DATASET. Filtrirali smo ga na srednjo in visoko vegetacijo, saj to ustreza kriterijem mejice. Zaradi iskanja najboljšega načina evidentiranja mejic z uporabo lidarsko zajetih podatkov sta bila preizkušena dva pristopa: pristop $1 \mathrm{oz}$. gostota krošenj ter pristop $2 \mathrm{oz}$. intenzivnost odboja.

Slika 8: Shematični prikaz uporabljenih metodoloških pristopov z lidarsko zajetimi podatki.

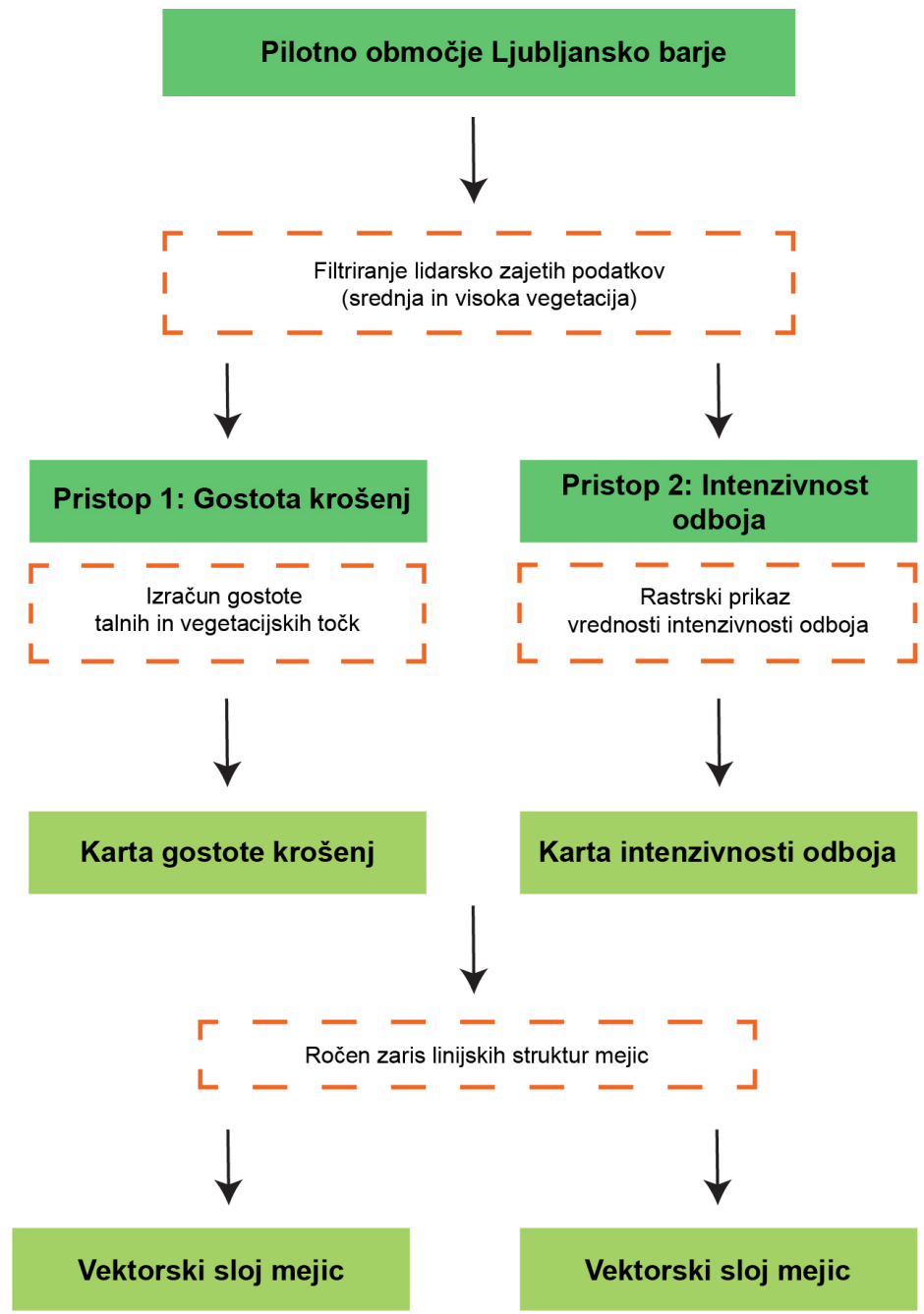


Na sliki 8 sta prikazana dva različna načina obdelave lidarskih podatkov, rezultat pa sta dva različna prostorska prikaza mejic. Gostota krošenj ali pokrovnost je ocena razmerja med tlemi in vrhovi krošenj, kot je vidno iz zraka. Izračunali smo jo s pomočjo podatkov o gostoti talnih in vegetacijskih točk. Metoda je uporabna za meritve $\mathrm{v}$ naravi, kot je npr. izračun biomase in vegetacijskega pokrova (Estimating forest canopy density ..., 2019).

Intenzivnost odboja ali intenziteta pomeni jakost odbitega signala oziroma razmerje med jakostjo sprejete svetlobe na laserskem skenerju. Uporablja se kot pripomoček pri identificiranju elementov in kot nadomestek za letalske posnetke. Sama karta je rastrski prikaz vrednosti izmerjene intenzivnosti odboja. Zajema eno valovno dolžino, in sicer človeku nevidni bližnji infrardeči del spektra, ki je le malo večja od valovnih dolžin vidnega spektra, zato je prikaz precej podoben dojemanju vidne svetlobe. Lahko ločimo gosto posnete točke, kot so drevesa, hiše ali ceste, še posebej na površju, brez višinskih razlik. Težko je predvidevati končni razpon vrednosti, saj so končne vrednosti odvisne od več spremenljivk, različnih senzorjev in so brez merske enote (Švab Lenarčič, Oštir, 2015).

$\mathrm{V}$ zaključni fazi smo še ročno zarisali linijske strukture mejic in tako dobili dva vektorska sloja. Vse analize so bile opravljene s programskim orodjem ArcMap 10.7.

\section{REZULTATI}

Prepoznavanje mejic v prostoru s pomočjo različnih postopkov (1. terensko zajemanje (2017), 2. dva pristopa, temelječa na lidarsko zajetih podatkih, 3. dva evidenčna sloja mejic (MKGP 2016 in 2018)) je za pilotno območje na Ljubljanskem barju dalo različne rezultate (preglednica 2). To se odraža v številu in skupni dolžini mejic, ki se med vsemi postopki opazno razlikujejo.

Preglednica 2: Pilotno območje Ljubljanskega barja - evidentirano število in dolžina mejic $z$ različnimi pristopi.

\begin{tabular}{|l|c|c|}
\hline Postopki & Število mejic & Skupna dolžina mejic (m) \\
\hline Evidenčni sloj mejic 2016 & 88 & 9.468 \\
\hline Terensko evidentiranje mejic 2017 & 122 & 11.427 \\
\hline Evidenčni sloj mejic 2018 & 101 & 10.536 \\
\hline Lidarsko zajeti podatki - gostota krošenj & 127 & 13.978 \\
\hline Lidarsko zajeti podatki - intenzivnost odboja & 130 & 12.788 \\
\hline
\end{tabular}

Vir podatkov: Bucik in sod., 2017; MKGP, 2016; $2018 \mathrm{~b}$. 
Analiza mejic iz obeh uradnih evidenčnih slojev mejic iz let 2016 in 2018 kaže, da je na obravnavanem pilotnem območju leta 2018 zabeleženo večje število in večja skupna dolžina mejic. Takšno stanje nas je presenetilo, saj se je v tem obdobju skupno število mejic na celotnem območju Ljubljanskega barja precej zmanjšalo, in sicer z 2952 na 2720. Manjša je bila tudi njihova skupna dolžina (za 50.000 m) (MKGP, 2016; 2018b). Ti podatki opozarjajo na vprašljivo primernost DOF posnetkov iz leta 2014, ki so bili uporabljeni za pripravo evidenčnega sloja mejic 2016.

Podrobneje smo se problema lotili na manjšem pilotnem območju, kjer je bilo leta 2016 v evidenčni sloj zajetih 88 mejic, dve leti kasneje pa 101 mejica. Vzrokov za takšne razlike je lahko več. Spremembe so vezane na območje s pretežno njivsko rabo. Analiza rabe tal $\mathrm{v}$ obeh letih kaže na opuščanje njiv in s tem na večje zaraščanje površin, kar lahko pripelje do nastanka novih mejic. K slabši natančnosti lahko prispeva že omenjeno prvo zajemanje mejic s starejših DOF posnetkov. Začetek izvajanja operacije Ohranjanje mejic (leta 2017) je vnesel spremembe v način upravljanja z mejicami, kar bi lahko vplivalo na njihov manjši posek. Glavne razlike med evidenčnim slojem in terenskim popisnim slojem so večinoma $\mathrm{v}$ grmovnih mejicah na njivskih površinah na vzhodnem delu območja. Grmovne mejice so namreč tip mejic, ki se najhitreje zaraste in verjetno zaradi tega še niso bile opazne na DOF posnetkih.

Glede na predstavljeno se rezultati evidenčnih slojev niso izkazali za optimalne, zato smo se odločili za razvoj dveh lastnih metodoloških pristopov, ki sta izvedena s pomočjo lidarsko zajetih podatkov in sta podrobneje opisana v metodološkem poglavju 5.

Karta gostota krošenj (D) nam prikazuje gostoto drevesnih in grmovnih krošenj. Mejice so bile vidne kot linijski prikazi krošenj. Pri evidentiranju mejic smo morali biti pozorni, da smo zajemali jasno vidne linijske zarasti, ki pa niso smele biti širše od dvajsetih metrov. Dve različni metodi (gostota krošenj in intenzivnost odboja), ki sta temeljili na lidarsko zajetih podatkih, sta dali različne rezultate. Razlog je v različnih stopnjah vidnosti in tudi v sami podobi mejic. Pri karti intenzivnosti odboja mejice predstavljajo pasovi, $\mathrm{v}$ katerih se ne prepozna oblik lesnate vegetacije, medtem ko lahko pri karti gostote krošenj prepoznamo krošnje, kar zagotavlja jasno vidnost tudi ožjih pasov vegetacije. 
Slika 9: Prikaz in primerjava različnega obsega evidentiranih mejic, prepoznanih po različnih metodah (na izseku pilotnega območja Ljubljanskega barja).
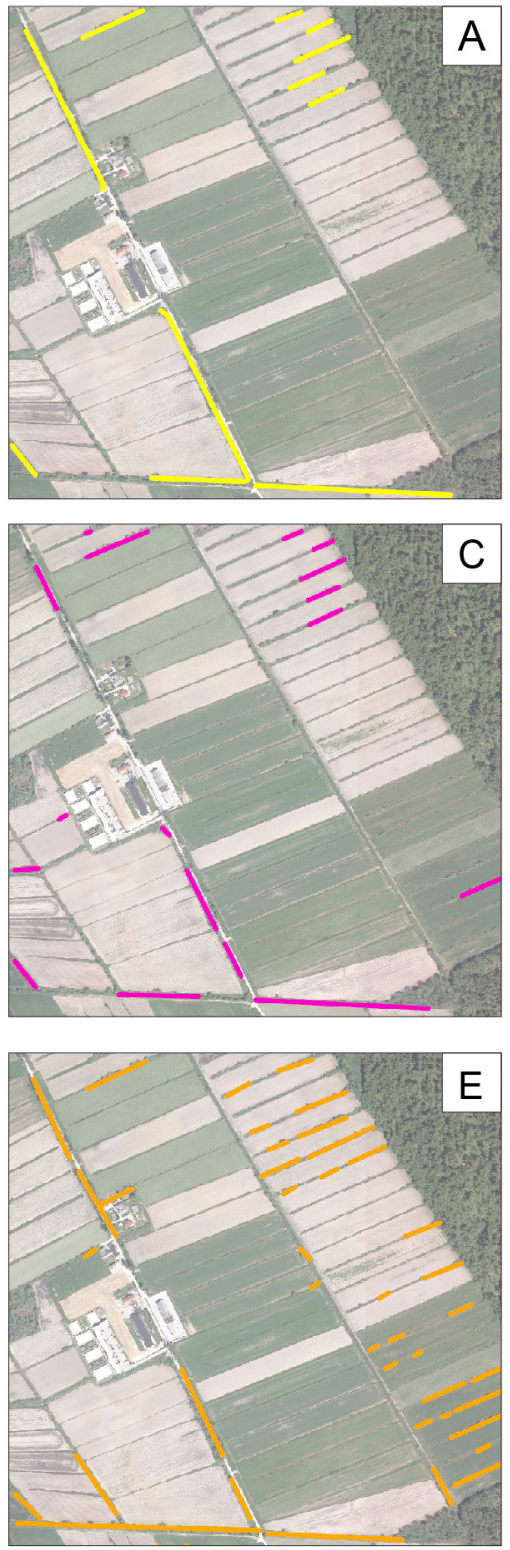
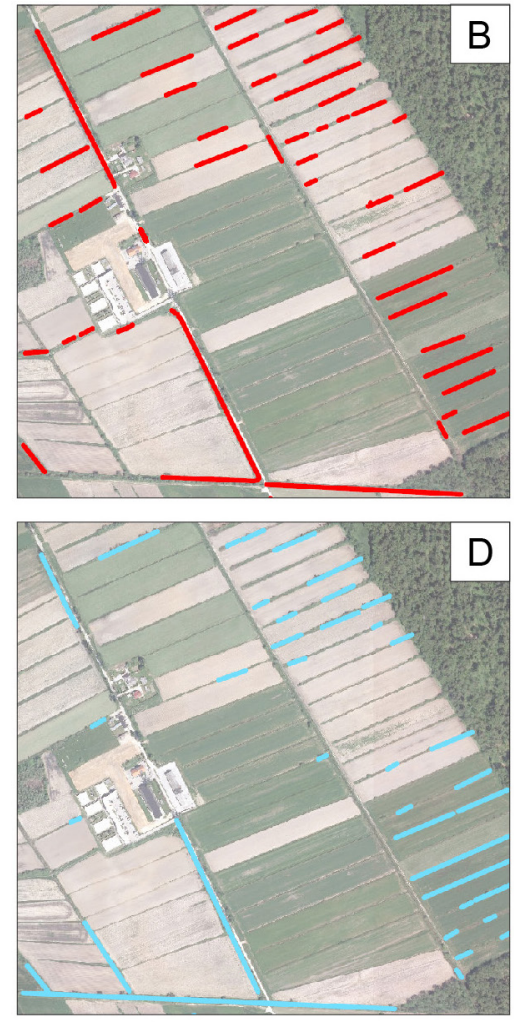

A evidenčni sloj mejic 2016

B terensko evidentiranje 2017

C evidenčni sloj mejic 2018 lidarsko zajeti podatkigostota krošenj lidarsko zajeti podatki intenzivnost odboja

Kartografija: Lea Rebernik, 2020 ARSO, 2015; Bucik in sod., 2017; GURS, 2016; MKGP 2016, 2018 
Preglednica 3: Število evidentiranih mejic z različnimi metodološkimi pristopi na pilotnem območju Ljubljanskega barja.

\begin{tabular}{|l|c|c|c|c|c|}
\hline Sloj mejic & $\begin{array}{c}\text { Evidenčni } \\
\text { sloj 2016 }\end{array}$ & $\begin{array}{c}\text { Evidenčni } \\
\text { sloj 2018 }\end{array}$ & $\begin{array}{c}\text { Terensko } \\
\text { evidentiranje } \\
2017\end{array}$ & $\begin{array}{c}\text { Lidarsko zajeti } \\
\text { podatki - } \\
\text { gostota krošenj }\end{array}$ & $\begin{array}{c}\text { Lidarsko zajeti } \\
\text { podatki - } \\
\text { intenzivnost } \\
\text { odboja }\end{array}$ \\
\hline $\begin{array}{l}\text { Evidenčni } \\
\text { sloj 2016 }\end{array}$ & +13 & +34 & +39 & +42 \\
\hline $\begin{array}{l}\text { Evidenčni } \\
\text { sloj 2018 }\end{array}$ & -13 & -21 & +21 & +26 & +29 \\
\hline $\begin{array}{l}\text { Terensko } \\
\text { evidentiranje } \\
\text { 2017 }\end{array}$ & -33 & -26 & -5 & +5 & +8 \\
\hline $\begin{array}{l}\text { Lidarsko } \\
\text { zajeti podat- } \\
\text { ki-gostota } \\
\text { krošenj }\end{array}$ & -39 & -29 & -8 & -3 & +3 \\
\hline $\begin{array}{l}\text { Lidarsko za- } \\
\text { jeti podatki - } \\
\text { intenzivnost } \\
\text { odboja }\end{array}$ & -42 & & & & \\
\hline
\end{tabular}

Vir podatkov: Bucik in sod., 2017; MKGP, 2016; $2018 \mathrm{~b}$.

Pri evidentiranju mejic na pilotnem območju Ljubljanskega barja je bilo prepoznanih najmanj mejic v obeh uradnih evidencah mejic (Evidenčni sloj 2016 in 2018). $S$ terenskim popisovanjem mejic ter slojema mejic, ki smo jih izdelali na osnovi lidarsko zajetih podatkov, smo evidentirali več mejic. Tudi razlike med temi tremi sloji mejic so razmeroma majhne in zato sklepamo, da so ti ustreznejši. 
Preglednica 4: Dolžine evidentiranih mejic ( $v$ metrih) z različnimi metodološkimi pristopi na Ljubljanskem barju.

\begin{tabular}{|l|c|c|c|c|c|}
\hline Sloj mejic & $\begin{array}{c}\text { Evidenčni } \\
\text { sloj 2016 }\end{array}$ & $\begin{array}{c}\text { Evidenčni } \\
\text { sloj 2018 }\end{array}$ & $\begin{array}{c}\text { Terensko } \\
\text { evidentiranje } \\
2017\end{array}$ & $\begin{array}{c}\text { Lidarsko zajeti } \\
\text { podatki - } \\
\text { gostota krošenj }\end{array}$ & $\begin{array}{c}\text { Lidarsko zajeti } \\
\text { podatki - } \\
\text { intenzivnost } \\
\text { odboja }\end{array}$ \\
\hline $\begin{array}{l}\text { Evidenčni sloj } \\
\mathbf{2 0 1 6}\end{array}$ & +1.068 & +1.959 & +4.510 & +3.320 \\
\hline $\begin{array}{l}\text { Evidenčni sloj } \\
\mathbf{2 0 1 8}\end{array}$ & -1.068 & -891 & +891 & +3.442 & +2.252 \\
\hline $\begin{array}{l}\text { Terensko } \\
\text { evidentiranje }\end{array}$ & -1.959 & -3.442 & -2.551 & +2.551 & +1.361 \\
\hline $\begin{array}{l}\text { Lidarsko zajeti } \\
\text { podatki - } \\
\text { gostota krošenj }\end{array}$ & -4.510 & -2.252 & -1.361 & +1.190 & -1.190 \\
\hline $\begin{array}{l}\text { Lidarsko zajeti } \\
\text { podatki - } \\
\text { intenzivnost } \\
\text { odboja }\end{array}$ & -3.320 & & & & \\
\hline
\end{tabular}

Vir podatkov: Bucik in sod., 2017; MKGP, 2016; $2018 \mathrm{~b}$.

Zanimivo je, da se evidenčni sloj mejic 2018 tako po številu kot po skupni dolžini mejic manj razlikuje od sloja mejic, evidentiranih s pomočjo lidarsko zajetih podatkov, kot evidenčni sloj 2016. Tak rezultat deloma preseneča zaradi manjše časovne razlike med DOF posnetki (ki so osnova za evidenčni sloj 2016) in lidarskimi posnetki, ki so bili zajeti med letoma 2014 in 2015 . Naši rezultati kažejo na slabšo natančnost uradnega evidenčnega sloja mejic 2016. Razlike med terenskim popisom in rezultati obeh lidarskih pristopov so manjše predvsem pri skupnem številu mejic, do razlik pa prihaja pri dolžini grmovnih mejic med njivami.

Ugotavljamo, da se na različnih posnetkih mejice vizualno različno dobro zaznajo. To vpliva na razlike v njihovih dolžinah pri vseh slojih, ki smo jih zajeli digitalno. Med analiziranjem podatkov smo zaznali več razlik med lidarskimi in DOF posnetki. Te razlike tudi nakazujejo prednosti oziroma slabosti uporabe enih oziroma drugih podatkovnih slojev. Pomembna tehnična razlika je že v velikosti datotek. Velikost lidarskega posnetka, ki meri en kvadratni kilometer, je $101 \mathrm{MB}$, medtem ko je DOF slika, ki prikazuje območje petih kvadratnih kilometrov, velika približno $315 \mathrm{MB}$. Tudi prepoznavanje mejic je na lidarskih slojih težje kot na slojih DOF, saj slednji omogočajo lažje in hitrejše prepoznavanje linijskih struktur mejic. Po drugi strani pa 
je prednost lidarskih podatkov $v$ tem, da jih je mogoče filtrirati, na ta način pa se na sliki lahko vidi samo srednja in visoka vegetacija, zato so linijske strukture bolj jasne in lažje prepoznavne kot na DOF posnetkih. Na lidarskih posnetkih tudi ni senc, ki se lahko pojavijo na posnetkih DOF in ovirajo vizualno prepoznavanje, hkrati pa je na lidarskih posnetkih laže zaznati vrzeli med mejicami. Omeniti še velja, da se pri evidentiranju mejic pri uporabi obeh posnetkov pojavlja problem prepoznavanja drevoredov in ostalih (linijskih) nasadov, ki ne sodijo med mejice.

\section{ZAKLJUČEK}

Operacija Ohranjanje mejic, ki se izvaja v okviru ukrepa KOPOP, predstavlja prvi sistemski poskus ohranjanja in vzdrževanja mejic v Sloveniji. Na sedmih območjih v Sloveniji (Krakovski gozd - Šentjernejsko polje, dolina Reke, dolina Vipave, Planinsko polje, Ljubljansko polje, Drava, Mura), kjer so mejice že opredeljene v evidenčnem sloju mejic, se je posledično med lastniki zemljišč, kmeti in kmetijskimi svetovalci začelo pogosteje naslavljati problematiko njihovega vzdrževanja in ohranjanja (Čuš, 2019; Žvikart, 2019). V novem programskem obdobju si lahko obetamo izboljševanje ter razširitev različnih prostorskih slojev za izvedbo naravovarstvenih podintervencij, kar bo v praksi pomenilo razširitev evidenčnega sloja mejic še na druga območja Slovenije (MKGP, 2021).

Zaradi prepoznanih težav naravovarstvenega in kmetijskega resorja, vezanih na kakovost in vzdrževanje uradne evidence mejic, iskanja učinkovitejših načinov popisovanja novih območij z mejicami in spremljanja njihovega vzdrževanja, smo se v raziskavi osredotočili na razvoj metod prepoznavanja in vzpostavljanja sloja mejic. Obstoječi sistem spremljanja in posodabljanja podatkov je pomanjkljiv in ne sledi dejanskim razmeram na terenu.

Naše podrobnejše raziskave na pilotnem območja Ljubljanskega barja med letoma 2017 in 2019 kažejo, da nobeden od treh preverjenih načinov prepoznavanja in evidentiranja mejic (z uporabo digitalnih ortofoto posnetkov, lidarsko zajetih podatkov, s terenskim delom) ni povsem ustrezen, vendar ima vsak pristop določene prednosti in slabosti. Ugotavljamo, da ažuren prostorski sloj mejic zahteva uporabo najnovejših dostopnih podatkov in različnih tehnik, kljub zamudnosti pa je treba metode kombinirati $s$ terenskimi ogledi in popisom. Evidentiranje mejic $\mathrm{z}$ uporabo lidarsko zajetih podatkov poleg pristopov, predstavljenih v prispevku, ponuja še druge možne rešitve, vendar bi že s predstavljenimi (in preizkušenimi) metodami prepoznavanja in evidentiranja zagotovo lahko razširili evidenčni sloj mejic tudi na druga območja v Sloveniji.

Zaključimo lahko, da se prikazi mejic, izdelani po različnih metodoloških pristopih, ki smo jih izvedli na pilotnem območju Ljubljanskega barja, razlikujejo. Razlike bi se verjetno pokazale tudi na drugih območjih mejic v Sloveniji. Med postopki sicer ne prihaja do velikih razhajanj v številu in dolžinah mejic, so pa razlike pomembne zaradi dejstva, da se kmetijska plačila za operacijo Ohranjanje mejic nanašajo na 
dolžinski meter mejice. Plačilo je v programskem obdobju 2014-2020 znašalo 1,6 EUR za tekoči meter mejice, namenjeno pa je izravnavi stroškov kmeta, ki nastanejo zaradi njihovega urejanja in vzdrževanja (MKGP, 2019).

Ker o obsegu in kakovosti mejic izven evidenčnega sloja trenutno v Sloveniji nimamo podatkov, ukrepi za ohranjanje pa se v okviru Operacije mejic drugod ne morejo izvajati, upravičeno pričakujemo, da bodo zaradi teženj v kmetijstvu in drugih prostorskih pritiskov te prvine v prostoru še bolj ogrožene. Obstoječo evidenco mejic je treba nadgraditi tudi v vsebinskem smislu. Trenutno se spremljata le dolžina in sklenjenost mejic, ne pa tudi njihova kakovost. Poskusno smo atribute za spremljanje razširili že v okviru naše raziskave, in sicer $\mathrm{z}$ dodatnim podatkom o tipu mejic. Na podlagi terenske opredelitve tipa mejice lahko bolje ocenimo oziroma sklepamo na obseg in kakovost funkcij, ki jih določena mejica lahko opravlja. Zaradi prepoznane kakovosti funkcij mejic bi laže opredelili območja, kjer je njihovo varovanje še posebej pomembno, oziroma območja z manj kakovostnimi mejicami, ki bi jih bilo treba izboljšati.

Prispevek nakazuje nekatere rešitve $\mathrm{v}$ smeri nadgradnje obstoječega nacionalnega evidenčnega sloja mejic. Za ohranjanje in učinkovito varovanje mejic bodo, poleg metodološko ustrezno podprtega evidentiranja, odločilnega pomena ukrepi in usmeritve s področij kmetijstva, varstva narave in urejanja prostora. Predvsem pa je potrebno kontinuirano ozaveščanje kmetov, lastnikov zemljišč in širše javnosti o številnih funkcijah mejic v kulturni kmetijski pokrajini.

\section{Literatura in viri}

Allende Álvarez, F., Gómez Mediavilla, G., López Estébanez, N., 2021. Environmental, demographic and policy drivers of change in Mediterranean hedgerow landscape (Central Spain). Land Use Policy, 103, 105342. DOI: 10.1016/j.landusepol.2021.105342.

Allende Álvarez, F., Gomez-Mediavilla, G., López-Estébanez, N., Molina Holgado, P., 2021. Classification of Mediterranean hedgerows: A methodological approximation. MethodsX, 8, 101355. DOI: 10.1016/j.mex.2021.101355.

Baudry, J., Bunce, R. G. H., Burel, F., 2000. Hedgerows. An international perspective on their origin, function and management. Journal of Environmental Management, 60, 1, str. 7-22. DOI: 10.1006/jema.2000.0358 .

Boutin, C., Jobin, B., Belanger, L., Choinere L., 2002. Plant diversity in three types of hedgerows adjacent to cropfields, Biodiversity \& Conservation, 11, 1, str. 1-25.

Bucik, J., Grbec, G., Kastelic, A., Pustavrh, M., Rigler, A., Strle, D., Šebela, M., Žemlja, K., 2017. Preverjanje, posodabljanje in izboljšanje evidence mejic na Ljubljanskem barju. Projektna naloga pri predmetu Izdelava okoljskih raziskovalnih projektov in presoj vplivov na okolje. Ljubljana, Oddelek za geografijo, Filozofska fakulteta, 46 str. Burel, F., Baudry, J., 1990. Hedgerow network patterns and processes in France. V: Zoonneveld, I. S., Forman, T. T. R. (ur.). Channing landscapes. An ecological perspective. Berlin: Springer-Verlag, str. 99-120. 
Čuš, J., 2019. Mejice skozi oči Ministrstva za kmetijstvo, gozdarstvo in prehrano (osebni vir, 29. 3. 2019). Ljubljana.

Domanjko, G., Malačič, K., 2009. Mejice so zaveznik kmetijskim kulturam. Mejice med neurji, njihovo izginjanje in nega. Krajinski park Goričko. URL:http://www. park-goricko.org/download/9/2009/9/3463_8428_Mejice_za_sejem_2009_GD_ KM.pdf (citirano 3. 3. 2019).

Dondina, O., Kataoka, L., Orioli, V., Bani, L., 2016. How to manage hedgerows as effective ecological corridors for mammals. A two-species approach. Agriculture, Ecosystem \&Environment, 231, 1, str. 283-290.

Earnshaw, S., 2004. Hedgerows for California agriculture. A resource guide. Davis: CAFF. URL: http://www.caff.org/wp-content/uploads/2010/07/Hedgerow_manual.pdf (citirano 17. 5. 2019).

Estimating forest canopy density and height. ARCGIS. URL: https://desktop.arcgis. com/en/arcmap/10.3/manage-data/las-dataset/lidar-solutions-estimating-forest-density-and-height.htm (citirano 11. 10. 2019).

Farmers and hedgerow management. RSPB. URL: https://www.rspb.org.uk/our-work/conservation/conservation-and-sustainability/advice/conservation-land-management-advice/farm-hedges/farmers-and-hedgerow-management/ (citirano 29. 1. 2019).

Forman, R., Baudry, J., 1984. Hedgerows and hedgerow networks in landscape ecology. Environmental Management, 6, str. 495-510. DOI: 10.1007/bf01871575.

Garratt, P. D. M., Senapathi, D., Coston, J. D., Mortimer, R. S., Potts, G. S., 2017. The benefits of hedgerows for pollinators and natural enemies depends on hedge quality and landscape context. Agriculture, Ecosystem \& Environment, 247, str 363-370.

Golobič, M., Penko Seidl, N., Lestan, K. A., Žerdin, M., Pačnik, L., Libnik, N., Vrbanjščak, M., Vrščaj, B., Kralj, T., Turk, B., Bergant, J., Šinkovec, M., 2015. Opredelitev krajinske pestrosti in krajinskih značilnosti, pomembnih za ohranjanje biotske raznovrstnosti. Ciljni raziskovalni program (CRP) »Zagotovimo si hrano za jutri« 2011-2020, končno poročilo projekta. Ljubljana: Univerza v Ljubljani, Biotehniška fakulteta.

Graham, L., Gaulton, R., Gerard, F., Staley, J. T., 2018. The influence of hedgerow structural condition on wildlife habitat provision in farmed landscapes. Biological Conservation, 220, str. 122-131. DOI: 10.1016/j.biocon.2018.02.017.

Heath, K. S., Soykan, U., Velas, L. K., Kelsey, R., Kroos, M. S., 2017. A bustle in the hedgerow. Woody field margins boost on farm avian diversity and abundance in an intensive agricultural landscape. Biological Conservation, 212, str. 153-161.

Hedgerow survey handbook. A standard procedure for local surveys in the UK. 2007. London: DEFRA. URL: https://assets.publishing.service.gov.uk/government/uploads/system/uploads/attachment_data/file/69285/pb11951-hedgerow-survey-handbook-070314.pdf (citirano 18. 1. 2019). 
Izvedba laserskega skeniranja Slovenije. Blok 35 - tehnično poročilo o izdelavi izdelkov. 2015. Geodetski inštitut Slovenije. URL: http://gis.arso.gov.si/related/lidar_ porocila/b_35_izdelava_izdelkov.pdf (citirano 10. 4. 2020).

Jančar, T., 2018. Popis pokošenosti na Ljubljanskem barju 2017 - popis rabe kmetijskih zemljišč s poudarkom na datumu košnje, verzija 2.0. Poročilo. Ljubljana: DOPPS.

Japelj, J., 2019. Mejice v Krajinskem parku Ljubljansko barje (Osebni vir, 17. 4. 2019). Ljubljana.

Kastelic, A., 2019. Mejice kot element slovenske kulturne pokrajine-stanje in vloga na primeru treh izbranih območjih. Magistrsko delo. Ljubljana: Univerza v Ljubljani, Filozofska fakulteta.

Kmetijstvo na Ljubljanskem Barju. Projekt Ljuba. URL: http://www.ljuba.si/narava-kmetijstvo/kmetijstvo/ (citirano 26. 2. 2019).

Lampič, B., Kušar, S., Lamovšek Zavodnik, A., 2017. Model celovite obravnave funkcionalno degradiranih območij kot podpora trajnostnemu prostorskemu in razvojnemu načrtovanju v Sloveniji. Dela, 48, str. 5-31. DOI: 10.4312/dela.48.2.5-59.

Litza, K., Alignier, A., Closset-Kopp, D., Ernoult, A., Mony, C., Osthaus, M., Staley, J., Van Den Berge, S., Vanneste, T., Diekmann, M., 2022. Hedgerows as a habitat for forest plant species in the agricultural landscape of Europe. Agriculture, Ecosystems \& Environment, 326, 107809. DOI: 10.1016/j.agee.2021.107809.

MKGP [Ministrstvo za kmetijstvo, gozdarstvo in prehrano], 2016. Mejice za operacijo Ohranjanje mejic (interni vir, 4. 7. 2018).

MKGP, 2018a. Grafični podatki RABA za celo Slovenijo. URL: http://rkg.gov.si/ GERK/ (citirano 10. 8. 2019).

MKGP, 2018b. Mejice za operacijo Ohranjanje mejic (interni vir, 4. 7. 2018).

MKGP, 2019. Navodila za izvajanje operacije ohranjanje mejic v okviru Kmetijsko-okoljskih-podnebnih plačil. 2. posodobitev. URL: https://www.program-podezelja.si/images/SPLETNA_STRAN_PRP_NOVA/5_Knji\%C5\%BEnica/Navodila_KRA_MEJ_kon_2018.pdf (citirano 11.1.2019).

MKGP, 2021. Skupni strateški načrt 2023-2027 za Slovenijo (osnutek). URL: https:// skp.si/uporabne-povezave/strateski-nacrta-skupna-kmetijska-politika-skp (citirano 6. 11.2021).

Molnarova, K., 2008. Long-term dynamics of the structural attributes of hedgerow networks in the Czech Republic. Three case studies in areas with preserved medieval field pattern. Journal of Landscape Studies, 1, str. 113-127.

Oreszczyn, S., Lane, A., 2000. The meaning of hedgerows in the English landscape: Different stakeholder perspectives and the implications for future hedge management. Journal of Environmental Management, 60, 1, str. 101-118. DOI: 10.1006/ jema.2000.0365.

Oštir, K., 2006. Daljinsko zaznavanje. Ljubljana: Inštitut za antropološke in prostorske študije, ZRC SAZU. 
Pavšič, J., 2008. Neživi svet Ljubljanskega barja, Geologija barja in njegovega obrobja. V: Pavšič, J. (ur.). Ljubljanski barje. Neživi svet, rastlinstvo, živalstvo, zgodovina in naravo varstvo. Ljubljana: Društvo slovenska matica, str. 6-16.

Pečjak, A., 2019. Mejice na zahodnem delu Ljubljanskega barja (osebni vir, 12. 4. 2019). Ljubljana.

Premrl, T., Turk., M., 2013. Drevesno-poljedelski podsistem na primeru protivetrnih pasov v Vipavski dolini. Gozdarski vestnik, 71, 5/6, str. 313-321.

Resolucija o Nacionalnem programu varstva okolja za obdobje 2020-2030 (ReNPVO20-30). Uradni list RS, št. 31/20. URL: http://www.pisrs.si/Pis.web/ pregledPredpisa?id=ODLO1985 (citirano 1. 8. 2020).

Sanchez, A, I., Lassaietta, L., McCollin, D., Bunce., R. G. H., 2010. The effect of hedgerow loss on microclimate in the Mediterranean region: An investigation in Central Spain. Agroforestry Systems, 78, 1, str. 13-25.

Stališče stičišča SVARUN. Končno stališče stičišča SVARUN: Krajinske značilnosti ključnega pomena za ohranjanje biodiverzitete. 2020. URL: https://www.program-podezelja.si/images/SPLETNA_STRAN_PRP_NOVA/Novice/2020/delavnica_SHERPA/SHERPA_Krajinske_zna\%C4\%8Dilnosti_stali\%C5\%A1\%C4\%8De_ SVARUN_slo.pdf (citirano 12.8.2020)

Strokovne podlage za ustanovitev Krajinskega parka Ljubljansko barje. 2007. Ljubljana: Zavod RS za varstvo narave, OE Ljubljana. URL: http://www.ljubljanskobarje. si/uploads/datoteke/strokovne_podlage_ohranjanje_narave.pdf (citirano 20. 2. 2019).

Šmid Hribar, M., 2008. Drevo kot dvopomenska dediščina. Magistrsko delo. Ljubljana, Biotehniška fakulteta, 200 str. URL: http://www.digitalna-knjiznica.bf.uni-lj.si/ md_smid_hribar_mateja.pdf (citirano 1.2.2019).

Švab Lenarčič, A.., Oštir, K., 2015. Uporaba lidarskih podatkov za klasifikacijo pokrovnosti. Ljubljana: ZRC SAZU, 113 str.

The hedgerow regulations. Legislation. 1997. URL: http://www.legislation.gov.uk/ uksi/1997/1160/contents/made (citirano 14. 5. 2019).

Zbirke prostorskih podatkov. E-prostor. URL: http://www.e-prostor.gov.si/zbirke-prostorskih-podatkov/topografski-in-kartografski-podatki/ortofoto/ (citirano 1. 2. 2019).

Žvikart, M., 2019. Pomen mejic za Zavod za Varstvo Narave RS (osebni vir, 22. 3. 2019). Ljubljana. 